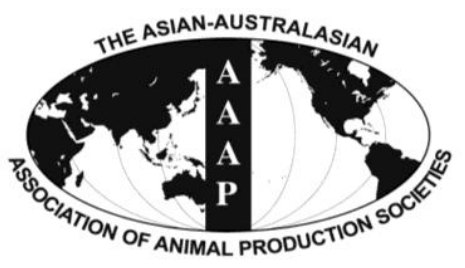

Asian-Aust. J. Anim. Sci.

Vol. 26, No. 4 : 529-536 April 2013

http://dx.doi.org/10.5713/ajas.2012.12607

www.ajas.info

pISSN 101 1-2367 elSSN 1976-5517

\title{
Effect of Carbohydrate Sources and Levels of Cotton Seed Meal in Concentrate on Feed Intake, Nutrient Digestibility, Rumen Fermentation and Microbial Protein Synthesis in Young Dairy Bulls
}

\author{
M. Wanapat*, N. Anantasook, P. Rowlinson ${ }^{1}$, R. Pilajun ${ }^{2}$ and P. Gunun \\ Tropical Feed Resources Research and Development Center (TROFREC), Department of Animal Science, \\ Faculty of Agriculture, Khon Kaen University, Khon Kaen 40002, Thailand
}

\begin{abstract}
The objective of this study was to investigate the effect of levels of cottonseed meal with various carbohydrate sources in concentrate on feed intake, nutrient digestibility, rumen fermentation and microbial protein synthesis in dairy bulls. Four, 6 months old dairy bulls were randomly assigned to receive four dietary treatments according to a $2 \times 2$ factorial arrangement in a $4 \times 4$ Latin square design. Factor A was carbohydrate source; cassava chip (CC) and cassava chip+rice bran in the ratio of 3:1 (CR3:1), and factor B was cotton seed meal levels in the concentrate; $109 \mathrm{~g} \mathrm{CP} / \mathrm{kg}$ (LCM) and $328 \mathrm{~g} \mathrm{CP} / \mathrm{kg}$ (HCM) at similar overall CP levels (490 g CP/kg). Bulls received urea-lime treated rice straw ad libitum and were supplemented with $10 \mathrm{~g}$ of concentrate $/ \mathrm{kg} \mathrm{BW}$. It was found that carbohydrate source and level of cotton seed meal did not have significant effects on ruminal $\mathrm{pH}$, ammonia nitrogen concentration, microbial protein synthesis or feed intake. Animals which received CC showed significantly higher BUN concentration, ruminal propionic acid and butyric acid proportions, while dry matter, organic matter digestibility, populations of total viable bacteria and proteolytic bacteria were lower than those in the CR3:1 treatment. The concentration of total volatile fatty acids was higher in HCM than LCM treatments, while the concentration of butyric acid was higher in LCM than HCM treatments. The population of proteolytic bacteria with the LCM treatments was higher than the HCM treatments; however other bacteria groups were similar among the different levels of cotton seed meal. Bulls which received LCM had higher protein digestibility than those receiving HCM. Therefore, using high levels of cassava chip and cotton seed meal might positively impact on energy and nitrogen balance for the microbial population in the rumen of the young dairy bull. (Key Words: Carbohydrate Source, Cotton Seed Meal, Rumen Fermentation, Microbial Population, Young Dairy Bull)
\end{abstract}

\section{INTRODUCTION}

Nutrition is very important for livestock production, especially the energy and protein source. Cassava (Manihot esculenta) tubers contain high levels of energy and have been used as a source of readily fermentable carbohydrate in ruminant rations; thus, allowing higher levels of urea be incorporated, (Wanapat, 2003; Promkot and Wanapat, 2005;

\footnotetext{
* Corresponding Author: Metha Wanapat. Tel: +66-43-202368, Fax: +66-43-202368, E-mail: metha@kku.ac.th

${ }^{1}$ School of Agriculture, Food and Rural Development Agriculture Building, Newcastle University, Newcastle upon Tyne, NE1 7RU, United Kingdom.

${ }^{2}$ Department of Animal Science, Faculty of Agriculture, Ubon Ratchathani University, Ubon Ratchathani 34190, Thailand. Submitted Nov. 1, 2012; Accepted Jan. 2, 2013; Revised Jan. 8, 2013
}

Khampa et al., 2006; Wanapat and Khampa, 2007). Increased daily weight gains and feed efficiency have also been reported when cassava replaced corn up to $20 \%$ in concentrates fed to buffalo calves (Etman et al., 1993). In addition, cassava successfully replaced corn or barley in studies on milk production in dairy cows fed grass silage or rice straw (Sommart et al., 1997; 2000).

Although soybean meal is a major protein source, byproducts from vegetable oil extract such as coconut meal, palm kernel meal, cotton seed meal, kapok seed meal, etc. and brewery's grain meal are also the protein sources available (Wanapat and Rowlinson, 2007). These local feeds have been used in several ruminant studies (Chanjula et al., 2004; Promkot and Wanapat, 2005; Khampa et al., 2006; Promkot et al., 2007; Wora-anu et al., 2007; Chantaprasarn and Wanapat, 2008; Wanapat et al., 2009a). 
Table 1. Ingredients and chemical compositions of dietary in the experiment $(\mathrm{g} / \mathrm{kg} \mathrm{DM})$

\begin{tabular}{|c|c|c|c|c|}
\hline & \multicolumn{2}{|c|}{ Energy source } & \multicolumn{2}{|c|}{ Protein source } \\
\hline & $\mathrm{CC}$ & CR3:1 & LCM & $\mathrm{HCM}$ \\
\hline \multicolumn{5}{|l|}{ Ingredient } \\
\hline Palm kernel meal & & & 461 & 347 \\
\hline Coconut meal & & & 385 & 297 \\
\hline Cottonseed meal & & & 109 & 328 \\
\hline Urea & & & 109 & 100 \\
\hline Tallow & & & 10 & 10 \\
\hline Molasses & & & 13 & 13 \\
\hline Salt & & & 5 & 5 \\
\hline Sulfur & & & 5 & 5 \\
\hline Mineral & & & 5 & 5 \\
\hline \multicolumn{5}{|l|}{ Chemical composition } \\
\hline Organic matter & 952 & 949 & 926 & 927 \\
\hline Crude protein & 24 & 49 & 491 & 490 \\
\hline Ether extract & 41 & 66 & 98 & 111 \\
\hline Neutral detergent fiber & 140 & 156 & 207 & 266 \\
\hline Acid detergent fiber & 123 & 137 & 154 & 187 \\
\hline
\end{tabular}

${ }^{1}$ CC = Cassava chip, $\mathrm{CR}=$ Cassava chip+rice bran (3:1), LCM = Llow cotton seedmeal, HCM = High cotton seed meal.

In addition, soybean meal has been successfully replaced by cottonseed meal or sunflower meal which are rich in rumen undegradable protein in fish (Margarida et al., 2002) and goat (Titi, 2003) diets. These could be beneficial for improvement of animal performance by incorporating with low degraded carbohydrate. Dairy cows fed with high level of cotton seed meal had a higher total feed intake, milk yield and composition, and milk income (Wanapat et al., 2012). Moreover, lambs fed with cottonseed meal increased NDF digestibility and $\mathrm{N}$ retention (Caton et al., 1988). However, differences of animal species can variably respond to dietary feed (Baldwin, 1998). Therefore, this study was conducted to investigate the effects of levels of cottonseed meal and carbohydrate sources on feed intake, nutrient digestibility, rumen fermentation, microbial population and microbial protein synthesis in dairy calf bulls.

\section{MATERIAL AND METHODS}

\section{Animals and feeds}

Four, 6 months old dairy bulls with an initial BW of $112 \pm 25 \mathrm{~kg}$ were randomly assigned to receive four dietary treatments according to a $2 \times 2$ factorial arrangement in a $4 \times 4$ Latin square design. Factor A was carbohydrate sources; cassava chip (CC) or Cassava chip+Rice bran in the ratio of 3:1 (CR3:1), and Factor B was cotton seed meal levels in concentrate; $109 \mathrm{~g} \mathrm{CP} / \mathrm{kg}$ (LCM) and $328 \mathrm{~g} \mathrm{CP} / \mathrm{kg}$ (HCM) at similar overall CP levels (490 g CP/kg). The ingredients and chemical composition of the carbohydrate sources and protein concentrates are presented in Table 1. The two sources of carbohydrate and two formulae of high protein concentrates were mixed to produce different rations to be isonitrogenous of $150 \mathrm{~g} \mathrm{CP} / \mathrm{kg}$ dry matter (Table 2). All dairy calf bulls were supplemented with

Table 2. Treatment combinations and chemical composition of dietary treatments (g/kg DM)

\begin{tabular}{lcccc}
\hline & $\mathrm{T} 1$ & $\mathrm{~T} 2$ & $\mathrm{~T} 3$ & $\mathrm{~T} 4$ \\
\cline { 2 - 5 } CC & $\mathrm{CC}+\mathrm{LCM}$ & $\mathrm{CC}+\mathrm{HCM}$ & $\mathrm{CR} 3: 1+\mathrm{LCM}$ & $\mathrm{CR} 3: 1+\mathrm{HCM}$ \\
$\mathrm{CR}$ & 730 & 730 & 771 & 771 \\
LCM & & & 229 & \\
HCM & 270 & & & 229 \\
Chemical composition & & 270 & & \\
$\quad$ Organic matter & 955 & 957 & 954 & 956 \\
Crude protein & 149 & 150 & 151 & 150 \\
Ether extract & 56 & 59 & 73 & 75 \\
Neutral detergent fiber & 145 & 149 & 155 & 166 \\
Acid detergent fiber & 127 & 135 & 136 & 142 \\
\hline
\end{tabular}

${ }^{1} \mathrm{CC}=$ cassava chip, RB = Rice bran, $\mathrm{CS}=$ cotton seed meal, LCM = low cotton seedmeal, HCM = high cotton seed meal. 
concentrate at $10 \mathrm{~g} / \mathrm{kg} \mathrm{BW}$, fed twice a day (0700 and 1600) and urea-lime treated rice straw (Wanapat et al., 2009b) was given ad libitum. Mineral blocks and water were available ad libitum for all animals in individual pens.

\section{Samples and analysis}

Feeds, feed refusals, urine and feces from the total collection of each individual calf during the last 7 days of each period were collected. On the day 21 of every period, rumen fluid and blood samples were collected at 0 and $4 \mathrm{~h}$ post feeding. Samples were stored at $-20^{\circ} \mathrm{C}$ and daily feces collections for each period were bulked, mixed and a 50 $\mathrm{g} / \mathrm{kg}$ sub-sample was taken (Singh et al., 2007).

Feeds, feed refusals and fecal samples were dried at $60^{\circ} \mathrm{C}$, ground $(1 \mathrm{~mm}$ screen using Cyclotech Mill, Tecator, Sweden) and proximate analysis performed using the standard methods of AOAC (1995) for dry matter (DM), ash and acid detergent fiber (ADF). Neutral detergent fiber (NDF) was estimated according to Van Soest et al. (1991). Total nitrogen $(\mathrm{N})$ in samples of feeds, feed refusals, urine and feces were determined according to AOAC (1991). Rumen fluid was immediately measured for $\mathrm{pH}$ using a portable $\mathrm{pH}$ temperature meter (HANNA, instruments HI 8424 microcomputer, Singapore) and $\mathrm{NH}_{3}-\mathrm{N}$ by Kjeltech Auto 1030 Analyzer (Bremmer and Keeney, 1965). Volatile fatty acids (VFA) were analyzed using High Performance Liquid Chromatography (Instuments by controller water model 600E; water model $484 \mathrm{UV}$ detector; column novapak C18; column size $3.9 \mathrm{~mm} \times 300 \mathrm{~mm}$; mobile phase $10 \mathrm{mM} \mathrm{H}_{2} \mathrm{PO}_{4}$ (pH 2.5)) according to Samuel et al. (1997). Rumen fluid was analysed for bacteria groups (total viable, cellulolytic, proteolytic and amylolytic bacteria) using the roll-tube technique of Hungate (1969).

Total urine excretion was collected and acidified using $10 \mathrm{ml}$ of $2 \mathrm{M} \mathrm{H}_{2} \mathrm{SO}_{4}$ solution. Urine samples were analyzed for allantoin concentration by High Performance Liquid
Chromatography, as described by Chen et al. (1993). The microbial $\mathrm{N}(\mathrm{MN})$ synthesis was estimated by the urinary excretion of purine derivatives (PD) according to Chen and Gomes (1995):

$$
\begin{aligned}
& \mathrm{Y}=0.85 \mathrm{X}+\left(0.385 \mathrm{BW}^{0.75}\right) \\
& \mathrm{MN}(\mathrm{g} / \mathrm{d})=70 \mathrm{X} /(0.116 \times 0.83 \times 1000)=0.727 \mathrm{X}
\end{aligned}
$$

where $\mathrm{X}$ and $\mathrm{Y}$ are the absorption and excretion of PD in $\mathrm{mmol} / \mathrm{d}$, respectively. Efficiency of microbial $\mathrm{N}$ supply (EMNS) was calculated using the following formula:

$$
\text { EMNS }=\text { microbial } N(g / d) / D O M R
$$

where DOMR = digestible OM apparently fermented in the rumen.

\section{Statistical analysis}

All data were analyzed as a $2 \times 2$ factorial arrangement in a $4 \times 4$ Latin square design using the general linear procedure in PROC GLM of SAS (1996). The statistical model included terms for animal, period, energy source, urea level, and the energy sourcexurea level interactions. Unless otherwise stated the significance is reported at $\mathrm{p}<0.05$.

\section{RESULTS AND DISCUSSION}

\section{Effect on feed intake and nutrients digestibility}

Carbohydrate sources and cotton seed meal levels did not affect urea-treated rice straw intake (Table 3) of animals while total intake, expressed as $\mathrm{g} / \mathrm{kg}$ of metabolic weight, tended to be higher in HCM group than LCM group $(\mathrm{p}<0.07)$. However, using CR3:1 as a carbohydrate source

\begin{tabular}{|c|c|c|c|c|c|c|c|c|}
\hline & \multicolumn{2}{|c|}{$\mathrm{CC}^{1}$} & \multicolumn{2}{|c|}{ CR3:1 } & \multirow{2}{*}{ SEM } & \multicolumn{3}{|c|}{ Significance $^{2}$} \\
\hline & LCM & $\mathrm{HCM}$ & LCM & $\mathrm{HCM}$ & & $\mathrm{CS}$ & $\mathrm{CM}$ & $\mathrm{I}$ \\
\hline ULTRS intake $(\mathrm{kg} / \mathrm{h} / \mathrm{d})$ & 1.8 & 1.7 & 1.7 & 1.7 & 0.32 & $\mathrm{~ns}$ & ns & $\mathrm{ns}$ \\
\hline Total intake $(\mathrm{kg} / \mathrm{h} / \mathrm{d})$ & 2.8 & 2.7 & 2.7 & 2.7 & 0.53 & ns & ns & ns \\
\hline $\mathrm{g} / \mathrm{kg} \mathrm{BW}$ & 24 & 25 & 24 & 24 & 0.41 & $\mathrm{~ns}$ & ns & ns \\
\hline $\mathrm{g} / \mathrm{kg} \mathrm{BW}^{0.75}$ & 74.6 & 75.1 & 74.9 & 76.6 & 0.91 & ns & 0.07 & $\mathrm{~ns}$ \\
\hline \multicolumn{9}{|c|}{ Apparent digestibility (g/kg DM) } \\
\hline Dry matter & 635 & 619 & 664 & 654 & 10.8 & $*$ & ns & $\mathrm{ns}$ \\
\hline Organic matter & 744 & 738 & 775 & 768 & 11.3 & $*$ & ns & ns \\
\hline Crude protein & 640 & 607 & 659 & 616 & 9.9 & ns & $*$ & ns \\
\hline Ether extract & 583 & 613 & 589 & 597 & 11.4 & ns & ns & ns \\
\hline Neutral detergent fiber & 621 & 626 & 639 & 633 & 1.03 & ns & ns & ns \\
\hline Acid detergent fiber & 483 & 473 & 509 & 508 & 1.53 & ns & ns & ns \\
\hline
\end{tabular}
resulted in higher DM and OM digestibility when compared

Table 3. Effect of carbohydrate sources and cotton seed meal levels on feed intakes and apparent nutrient digestibility

\footnotetext{
${ }^{1}$ CC = Cassava chip, CR3:1 = Cassava chip+rice bran 3:1, LCM = Low cotton seed meal, HCM = High cotton seed meal.

${ }^{2} \mathrm{CS}=$ Energy sources, $\mathrm{CM}=$ Cotton seed meal levels, $\mathrm{I}=\mathrm{ES} \times \mathrm{CM}$ interaction.

$* \mathrm{p}<0.05, \mathrm{~ns}=$ Non-significant difference, $\mathrm{SEM}=$ Standard error of the means.
} 
Table 4. Effect of carbohydrate sources and cotton seed meal levels on ruminal $\mathrm{pH}$, ammonia nitrogen and urea nitrogen concentration

\begin{tabular}{|c|c|c|c|c|c|c|c|c|c|}
\hline & & \multicolumn{2}{|c|}{$\overline{\mathrm{CC}^{1}}$} & \multicolumn{2}{|c|}{$\mathrm{CR}$} & \multirow{2}{*}{ SEM } & \multicolumn{3}{|c|}{ Significance $^{2}$} \\
\hline & & LCM & $\mathrm{HCM}$ & LCM & $\mathrm{HCM}$ & & $\mathrm{CS}$ & $\mathrm{CM}$ & $\mathrm{I}$ \\
\hline \multirow{3}{*}{$\begin{array}{l}\text { Ruminal } \mathrm{pH} \\
\text { h-post feeding }\end{array}$} & 0 & 6.6 & 6.7 & 6.6 & 6.8 & 0.13 & $\mathrm{~ns}$ & ns & $\mathrm{ns}$ \\
\hline & 4 & 6.4 & 6.4 & 6.4 & 6.3 & 0.06 & ns & ns & ns \\
\hline & mean & 6.5 & 6.6 & 6.5 & 6.6 & 0.05 & $\mathrm{~ns}$ & ns & $\mathrm{ns}$ \\
\hline \multirow{3}{*}{$\begin{array}{l}\mathrm{NH}_{3}-\mathrm{N}, \mathrm{mg} / \mathrm{dl} \\
\text { h-post feeding }\end{array}$} & 0 & 7.1 & 6.8 & 7.4 & 7.4 & 0.61 & ns & ns & ns \\
\hline & 4 & 8.4 & 10.2 & 8.3 & 7.7 & 0.99 & ns & ns & $\mathrm{ns}$ \\
\hline & mean & 7.8 & 8.5 & 7.9 & 7.6 & 0.45 & ns & ns & $\mathrm{ns}$ \\
\hline \multirow{3}{*}{$\begin{array}{l}\text { BUN, mg/dl } \\
\text { h-post feeding }\end{array}$} & 0 & 7.0 & 7.1 & 6.8 & 7.0 & 0.20 & ns & ns & $\mathrm{ns}$ \\
\hline & 4 & 10.3 & 10.8 & 7.8 & 9.3 & 0.80 & * & ns & ns \\
\hline & mean & 8.7 & 9.4 & 7.3 & 8.2 & 1.00 & $*$ & ns & ns \\
\hline
\end{tabular}

${ }^{1}$ CC = Cassava chip, CR3:1= Cassava chip+rice bran 3:1, LCM = Low cotton seed meal, HCM = High cotton seed meal.

${ }^{2} \mathrm{CS}=$ Energy sources, $\mathrm{CM}=$ Cotton seed meal levels, $\mathrm{I}=\mathrm{ES} \times \mathrm{CM}$ interaction.

$* \mathrm{p}<0.05, \mathrm{~ns}=$ Non-significant difference, $\mathrm{SEM}=$ Standard error of the means.

with CC treatments $(\mathrm{p}<0.05)$. Moreover, bulls which received $\mathrm{LCM}$ had higher protein digestibility than the HCM treatments $(\mathrm{p}<0.05)$ but, digestibility of ether extract and fiber were not affected by either carbohydrate sources or levels of cotton seed meal in the concentrate $(p>0.05)$. Sarwar et al. (1991) reported the intake of dry matter to be inversely related to digestibility in cattle. Using a high level of easily degradable carbohydrate feedstuffs may impact on feed intake due to a higher rate of VFA production, a drop in ruminal pH (Sommart et al., 1997; Richardson et al., 2003; Wang et al., 2009), and a decrease in microbial fermentation in the rumen (Firkins, 1996; Rusell and Rychlik, 2001; Firkins et al., 2006). Ruminal microorganisms play an important role in feed digestion of ruminants, particularly the fiber fraction (Russell and Rychlik, 2001). Thus the differences in nutrient digestibility in this study could be attributed to the higher microbial populations in the $\mathrm{CC}$ and LCM treatments. Moreover, the rumen undegradable protein and non-structural carbohydrate intakes could also affect the nutrient digestibility. Bruckental et al. (2002) found digestibility of $\mathrm{CP}$ and non-structural carbohydrate increased when the proportion of undegradable protein was increased. In contrast, the result of $\mathrm{CP}$ digestibility in current studies showed negative effect when undegradable protein was increased.

\section{Effect on rumen fermentation characteristics and blood metabolites}

Ruminal $\mathrm{pH}$ in present study was similar among carbohydrate sources (Table 4) and similar to values obtained by other worker (6.5 to 6.9) (Chanjula et al., 2004; Granum et al., 2007; Wanapat et al., 2009a). This result indicated that a combination of an appropriate carbohydrate source with a high protein concentrate feed may improve rumen fermentation by providing suitable $\mathrm{pH}$ conditions for microorganism activity as mentioned by Hungate (1966).
However, Khan et al. (2007) found that alterations in starch intake and starch fermentation pattern resulted in differences in ruminal $\mathrm{pH}$, which was contrast with this work. This could be due to suitable carbohydrate source and undegradable protein in the rumen. Ammonia nitrogen concentration was not affected by carbohydrate sources, levels of cottonseed meal or its interaction, and showed quite low levels (7.6 to $8.5 \mathrm{mg} / \mathrm{dl})$ when compared with other works (Chanjula et al., 2004; Granum et al., 2007; Wanapat and Pilajan, 2009; Foiklang and Wanapat, 2010). This result may imply that rumen microbial activity was limited by the protein digestibility of the local feedstuff, or the rumen microorganisms had a high level of ammonia assimilation for use as a nitrogen source for their protein synthesis (Erfle et al., 1976). In addition, Aldrich et al. (1993) reported a tendency for decreasing rumen $\mathrm{NH}_{3}-\mathrm{N}$ concentrations as starch degradability increased. In the present work, animals, which received $\mathrm{CC}$ as the carbohydrate source showed higher BUN concentration than the CR3:1 treatment at 4 and $6 \mathrm{~h}$ post feeding. This could be because cassava chip is more easily degraded in the rumen compared to the cassava chip combined with rice bran (Wanapat and Khampa, 2007). Accordingly, the rumen microorganisms have a high ammonia assimilation to use as a nitrogen source for their protein synthesis. Levels of cottonseed meal in the concentrate did not affect ruminal $\mathrm{pH}$, ammonia nitrogen or blood urea nitrogen concentrations. This could be due to efficiency of animals to use nitrogen for microbial protein synthesis. However, Rusche et al. (1993) found that feeding sources of protein that had a higher potential to be degraded in the rumen increased the concentration of plasma urea nitrogen (PUN) of primiparous beef cows. Moreover, Corbett and Edey (1977) reported reduced PUN in ewes fed formaldehydetreated casein compared with ewes fed isonitrogenous diets supplemented with untreated casein. 
Table 5. Effect of carbohydrate sources and cotton seed meal levels on volatile fatty acid concentration in rumen fluid

\begin{tabular}{|c|c|c|c|c|c|c|c|c|c|}
\hline & & \multicolumn{2}{|c|}{$\mathrm{CC}^{1}$} & \multicolumn{2}{|c|}{$\mathrm{CR}$} & \multirow[t]{2}{*}{ SEM } & \multicolumn{3}{|c|}{ Significance $^{2}$} \\
\hline & & LCM & HCM & LCM & $\mathrm{HCM}$ & & $\mathrm{CS}$ & $\mathrm{CM}$ & I \\
\hline \multicolumn{10}{|l|}{ Total VFA, mmol/L } \\
\hline \multirow[t]{4}{*}{ h-post feeding } & 0 & 90.8 & 93.7 & 95.4 & 97.1 & 1.24 & $\mathrm{~ns}$ & ns & $\mathrm{ns}$ \\
\hline & 4 & 91.7 & 96.7 & 96.8 & 98.8 & 2.04 & ns & ns & ns \\
\hline & mean & 91.3 & 94.2 & 96.1 & 98.0 & 1.40 & $\mathrm{~ns}$ & $*$ & $\mathrm{~ns}$ \\
\hline & & 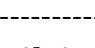 & $----n$ & nol ---- & -------- & & & & \\
\hline \multirow[t]{3}{*}{$\mathrm{C} 2$, h-post feeding } & 0 & 68.6 & 71.9 & 71.6 & 70.2 & 0.75 & $\mathrm{~ns}$ & ns & $\mathrm{ns}$ \\
\hline & 4 & 68.1 & 70.4 & 70.2 & 71.5 & 0.87 & ns & ns & ns \\
\hline & mean & 68.4 & 71.2 & 70.9 & 70.9 & 0.57 & $\mathrm{~ns}$ & ns & $\mathrm{ns}$ \\
\hline \multirow[t]{3}{*}{ C3, h-post feeding } & 0 & 22.1 & 19.1 & 19.4 & 21.1 & 0.50 & $\mathrm{~ns}$ & ns & $\mathrm{ns}$ \\
\hline & 4 & 21.9 & 20.7 & 20.9 & 20.1 & 0.62 & $\mathrm{~ns}$ & ns & $\mathrm{ns}$ \\
\hline & mean & 22.0 & 19.9 & 20.3 & 20.6 & 0.46 & $\mathrm{~ns}$ & ns & ns \\
\hline \multirow[t]{3}{*}{$\mathrm{C} 4$, h-post feeding } & 0 & 9.2 & 8.9 & 9.0 & 8.7 & 0.19 & $\mathrm{~ns}$ & ns & ns \\
\hline & 4 & 9.7 & 9.0 & 8.9 & 8.4 & 0.21 & $*$ & ns & $\mathrm{ns}$ \\
\hline & mean & 9.5 & 8.9 & 9.0 & 8.6 & 0.20 & $\mathrm{~ns}$ & ns & ns \\
\hline \multirow[t]{3}{*}{$\mathrm{C} 2: \mathrm{C} 3$, h-post feeding } & 0 & 2.7 & 3.3 & 3.7 & 3.3 & 0.31 & $*$ & ns & ns \\
\hline & 4 & 3.2 & 3.5 & 3.4 & 3.6 & 0.15 & $\mathrm{~ns}$ & ns & $\mathrm{ns}$ \\
\hline & mean & 3.0 & 3.4 & 3.6 & 3.5 & 0.10 & $\mathrm{~ns}$ & ns & $\mathrm{ns}$ \\
\hline
\end{tabular}

${ }^{1}$ CC = Cassava chip, CR3:1 = Cassava chip+rice bran 3:1, LCM = Low cotton seed meal, HCM = High cotton seed meal.

${ }^{2} \mathrm{CS}=$ Energy sources, $\mathrm{CM}=$ Cotton seed meal levels, $\mathrm{I}=\mathrm{ES} \times \mathrm{CM}$ interaction.

$* \mathrm{p}<0.05, \mathrm{~ns}=$ Non-significant difference, $\mathrm{SEM}=$ Standard error of the means.

The combination of cassava chip with rice bran at the ratio of 3 to 1 (CR3:1) (Table 5) was decreased the proportions of propionic and butyric acid which could be ascribed to the significantly greater starch consumption in $\mathrm{CC}$ animals and probable superior fermentation of organic matter by ruminal microbes (Owen et al., 1967; Baldwin et al., 2004). Moreover, greater metabolic activity of the rumen epithelium and increased rumen absorptive area in animals was associated with a higher organic matter fermentation and higher concentrations of VFA in the rumen (Owen et al., 1967; Lesmeister and Heinrichs, 2004). Animals which received HCM had a higher concentration of total VFA than the LCM treatments. This may be attributed to higher degradation by ruminal microbes in the HCM treatment in agreement with Dijkstra (1994) who reported that the production of VFA in the rumen was linearly correlated with dry matter intake of ruminants. However, Keady and Mayne (2001) found that the molar concentration of total volatile fatty acids did not increase as total feed intake increased. Bannink et al. (2006) estimated the stoichiometry of VFA production in the rumen of lactating cows and found many factors that affected concentration and proportions of volatile fatty acids, such as dry matter intake, diet composition, truly digested in the rumen, and the utilization rate of substrate by rumen microorganisms, etc.

\section{Effect on rumen microbial population}

Effects of carbohydrate source and cottonseed meal levels on microbial populations in the rumen of the young dairy bulls are in Table 6. Animals fed with CC had lower $(p<0.05)$ populations of both total viable bacteria and proteolytic bacteria than the CR3:1 treatment, while the populations of cellulolytic bacteria and amylolytic bacteria were not significantly different among treatments $(p>0.05)$. This result could be due to the lower DM and OM digestibility of the $\mathrm{CC}$ treatment as the ruminal microorganisms play a vital role in feed digestion of ruminants (Russell and Rychlik, 2001). However, it might be expected that the population of amylolytic bacteria in the rumen should increase when ruminants receive more easily degradable carbohydrates (Hungate, 1966; Tajima et al., 2001). The population of proteolytic bacteria in animals fed LCM was higher than HCM which could be due to the nature of the protein in cottonseed meal which is highly rumen undegradable (Clark et al., 1987; 1992), according to Bach et al. (2005) who concluded that the population of protelytic bacteria should decrease when ruminants receive a high proportion of rumen undegradable protein. However, other bacteria groups were similar between the two levels of cotton seed meal in the concentrate ( $p>0.05)$. In addition, numbers of bacteria in the rumen are dependant on many factors such as rate of passage, population of rumen protozoa, and other unknown factors (Hungate, 1966).

\section{Effect on microbial protein synthesis}

Table 7 shows the effect of carbohydrate source and cottonseed meal level on microbial protein synthesis. 
Table 6. Effect of carbohydrate sources and cotton seed meal levels on microbial population in the rumen

\begin{tabular}{|c|c|c|c|c|c|c|c|c|c|}
\hline & & \multicolumn{2}{|c|}{$\mathrm{CC}^{1}$} & \multicolumn{2}{|c|}{ CR3:1 } & \multirow{2}{*}{ SEM } & \multicolumn{3}{|c|}{ Significance $^{2}$} \\
\hline & & LCM & $\mathrm{HCM}$ & LCM & $\mathrm{HCM}$ & & $\mathrm{CS}$ & $\mathrm{CM}$ & I \\
\hline \multicolumn{10}{|c|}{ Total viable bacterial $\left(\times 10^{10} \mathrm{CFU}^{3} / \mathrm{ml}\right)$} \\
\hline \multirow[t]{2}{*}{ h-post feeding } & 0 & 2.9 & 3.0 & 5.0 & 4.4 & 0.86 & $*$ & ns & ns \\
\hline & 4 & 2.5 & 4.9 & 5.2 & 5.8 & 1.13 & $*$ & ns & $\mathrm{ns}$ \\
\hline mean & & 2.7 & 3.9 & 5.6 & 4.9 & 0.85 & $*$ & ns & ns \\
\hline \multicolumn{10}{|c|}{ Cellulolytic bacteria $\left(\times 10^{8} \mathrm{CFU} / \mathrm{ml}\right)$} \\
\hline \multirow[t]{2}{*}{ h-post feeding } & 0 & 3.9 & 3.5 & 4.1 & 3.4 & 1.19 & ns & ns & ns \\
\hline & 4 & 3.5 & 4.1 & 3.6 & 3.1 & 1.25 & ns & ns & ns \\
\hline mean & & 3.7 & 3.9 & 3.8 & 3.3 & 0.88 & ns & ns & $\mathrm{ns}$ \\
\hline \multicolumn{10}{|c|}{ Proteolytic bacteria $\left(\times 10^{7} \mathrm{CFU} / \mathrm{ml}\right)$} \\
\hline \multirow[t]{2}{*}{ h-post feeding } & 0 & 5.4 & 4.4 & 3.1 & 5.1 & 0.73 & ns & ns & $*$ \\
\hline & 4 & 4.2 & 3.2 & 6.8 & 4.2 & 1.82 & $*$ & $*$ & ns \\
\hline mean & & 4.8 & 3.8 & 4.5 & 4.6 & 0.92 & ns & ns & ns \\
\hline \multicolumn{10}{|c|}{ Amylolytic bacterial $\left(\times 10^{7} \mathrm{CFU} / \mathrm{ml}\right)$} \\
\hline \multirow[t]{2}{*}{ h-post feeding } & 0 & 3.8 & 5.9 & 4.1 & 4.4 & 1.09 & ns & ns & $\mathrm{ns}$ \\
\hline & 4 & 5.3 & 6.5 & 5.2 & 4.9 & 1.38 & $\mathrm{~ns}$ & ns & $\mathrm{ns}$ \\
\hline mean & & 4.5 & 6.2 & 4.7 & 4.7 & 1.00 & ns & ns & ns \\
\hline
\end{tabular}

${ }^{1}$ CC = Cassava chip, CR3:1 = Cassava chip+rice bran 3:1, LCM = Low cotton seed meal, HCM = High cotton seed meal.

${ }^{2} \mathrm{CS}=$ Energy sources, $\mathrm{CM}=$ Cotton seed meal levels, $\mathrm{I}=\mathrm{ES} \times \mathrm{CM}$ interaction.

${ }^{3} \mathrm{CFU}=$ Colony forming unit, $* \mathrm{p}<0.05, \mathrm{~ns}=$ Non-significant difference, $\mathrm{SEM}=$ Standard error of the means.

Microbial protein synthesis and its efficiency were not significantly affected by source of carbohydrates or levels of cotton seed meal in the concentrate, although populations of bacteria were significantly different $(p<0.05)$. Nevertheless, rate of ruminal degradability of nitrogen and carbohydrate sources, rumen dilution rate, dietary sulfur and frequency of feeding, also affect microbial protein synthesis (Stern and Hoover, 1979). The increase in nutrient digestibility in this study could attribute to higher microbial protein synthesis. Moreover, the microbial purine derivative absorption and microbial protein supply were affected by an interaction between carbohydrate source and level of cottonseed meal in the concentrate. The possible explanation for this result was unclear; however, synchronization between soluble carbohydrate and rumen degradable protein fractions in the rumen is a possible cause.

Another aim of this research was to present an alternative high protein concentrate, for use in small scale ruminant production, which could be easily combined with local carbohydrate sources for small-holder farmers.

\section{CONCLUSIONS}

Young dairy bulls which received $\mathrm{CC}$ showed higher blood urea nitrogen concentrations and ruminal proportions of propionic and butyric acids, while dry matter and organic matter digestibility and populations of total viable bacteria and proteolytic bacteria were lower than the CR3:1 fed treatments. Animals which received LCM had a lower concentration of total VFA, but showed a higher protein digestibility, butyric acid concentration, and proteolytic bacteria population than the HCM fed animals. In addition, there were some interactions between carbohydrate sources and cottonseed meal levels. Therefore, using high levels of cassava chip and cotton seed meal might positively impact on energy and nitrogen balance in the rumen of young dairy bulls.

Table 7. Effect of carbohydrate sources and cotton seed meal levels on microbial protein synthesis

\begin{tabular}{|c|c|c|c|c|c|c|c|c|}
\hline & \multicolumn{2}{|c|}{$\mathrm{CC}^{1}$} & \multicolumn{2}{|c|}{ CR3:1 } & \multirow{2}{*}{ SEM } & \multicolumn{3}{|c|}{ Significance $^{2}$} \\
\hline & LCM & $\mathrm{HCM}$ & LCM & $\mathrm{HCM}$ & & $\mathrm{CS}$ & $\mathrm{CM}$ & I \\
\hline PD excretion (mM/d) & 69.9 & 81.8 & 84.7 & 77.4 & 4.25 & $\mathrm{~ns}$ & ns & 0.07 \\
\hline PD absorption (mM/d) & 58.4 & 63.5 & 73.1 & 63.2 & 3.96 & $*$ & ns & $*$ \\
\hline MPS, g N/d & 42.4 & 46.2 & 53.1 & 46.0 & 4.22 & $\mathrm{~ns}$ & $\mathrm{~ns}$ & * \\
\hline EMPS, gN/kg OMDR & 29.1 & 30.3 & 31.2 & 29.2 & 2.28 & ns & ns & ns \\
\hline
\end{tabular}

${ }^{1}$ CC = Cassava chip, CR3:1 = Cassava chip+rice bran 3:1, LCM = Low cotton seed meal, HCM = High cotton seed meal.

${ }^{2} \mathrm{CS}=$ Energy sources, $\mathrm{CM}=$ Cotton seed meal levels, $\mathrm{I}=\mathrm{ES} \times \mathrm{CM}$ interaction.

$* \mathrm{p}<0.05, \mathrm{~ns}=$ Non-significant difference, $\mathrm{SEM}=$ Standard error of the means.

$\mathrm{PD}=$ Purine derivative, MPS = Microbial protein synthesis, EMPS = Efficiency of microbial protein synthesis.

OMDR = Organic matter digestible in the rumen (65\% of organic matter digestible in total tract) according to ARC (1984). 


\section{ACKNOWLEDGEMENTS}

The authors would like to express their most sincere gratitude and appreciation to the Tropical Feed Resources Research and Development Center (TROFREC), The Office of the Higher Education Commission and Thailand Research Fund (TRF) through the Royal Golden Jubilee Ph.D. Program, Department of Animal Science, Faculty of Agriculture, Khon Kaen University, for their financial support, experimental animals, laboratory research and the use of research facilities.

\section{REFERENCES}

Aldrich, J. M., L. D. Muller, G. A. Varga and L. C. Jr. Griel. 1993. Non structural carbohydrate and protein effects on rumen fermentation, nutrient flow, and performance of dairy cows. J. Dairy Sci. 76:1091-1105.

AOAC. 1991. Official methods of analysis. Association of Official Analysis Chemists, DC, USA. p. 1230.

AOAC. 1995. Official method of analysis, $16^{\text {th }}$ ed. Animal Feeds: Association of Official Analytical Chemists, Virginia, USA, pp. 1-18.

Bach, A., S. Calsamiglia and M. D. Stern. 2005. Nitrogen metabolism in the rumen. J. Dairy Sci. 88:E9-E21.

Baldwin, R. L. VI. 1998. Use of isolated ruminal epithelial cells in the study of rumen metabolism. J. Nutr. 128:293S-296S.

Baldwin, R. L. VI., K. R. McLeod, J. L. Klotz and R. N. Heitmann. 2004. Rumen development, intestinal growth and hepatic metabolism in the pre- and post-weaning ruminant. J. Dairy Sci. 87:E55-E65.

Bannink, A., J. Kogut, J. Dijkstra, J. France, E. Kebreab, A. M. Van Vuuren and S. Tamming. 2006. Estimation of the stoichiometry of volatile fatty acid production in the rumen of lactating cows. J. Theor. Biol. 238:36-51.

Bremmer, J. M. and D. R. Keeney. 1965. Steam distillation methods to determination of ammonium, nitrate and nitrite. Anal. Chim. Acta. 32:485-495.

Bruckental, I., S. M. Abramson, S. M. Zamwel, G. Adin and A. Ariel. 2002. Effect of dietary undegradable crude protein level on total nonstructural carbohydrate (TNC) digestibility and milk yield and composition of dairy cows. Livest. Prod. Sci. 76:71-79.

Caton, J. S., W. C. Hoefler, M. L. Galyean and M. A. Funk. 1988. Influence of cottonseed meal supplementation and cecal antibiotic infusion in lambs fed low-quality forage. I. Intake, digestibility, nitrogen balance and ruminal and cecal digesta kinetics. J. Anim. Sci. 66:2253-2261.

Chanjula, P., M. Wanapat, C. Wachirapakorn and P. Rowlinson. 2004. Effect of synchronizing starch sources and protein (NPN) in the rumen on feed intake, rumen microbial fermentation, nutrient utilization and performance of lactating dairy cows. Asian-Aust. J. Anim. Sci. 17:1400-1410.

Chantaprasarn, N. and M. Wanapat. 2008. Effects of sunflower oil supplementation in cassava hay based-diets for lactating dairy cows. Asian-Aust. J. Anim. Sci. 21:42-50.

Chen, X. B. and M. J. Gomes. 1995. Estimation of microbial protein supply to sheep and cattle based on urinary excretion of purine perivatives -an overview of the technical details. Occasional Publication 1992. International Feed Resources Unit, Rowett Research Institute, Aberdeen, UK.

Chen, X. B., D. J. Kyle and E. R. Orskov. 1993. Measurement of allantoin in urine and plasma by high-performance liquid chromatography with pre-column derivatization. J. Chromathogr. 617:241-247.

Clark, J. H., T. H. Klusmeyer and M. R. Cameron. 1992. Microbial protein synthesis and flows of nitrogen fractions to the duodenum of dairy cows. J. Dairy Sci. 75:2304-2323.

Clark, J. H., M. R. Murphy and B. A. Crooker. 1987. Supplying the protein needs of dairy cattle from by-product feeds. J. Dairy Sci. 70:1092-1109.

Corbtt, J. C. and T. N. Edey. 1977. Ovulation in ewes given formaldehyde-treated or untreated casein in maintenanceenergy rations. Aust. J. Agric. Res. 28:491-500.

Dijkstra, J. 1994. Production and absorption of volatile fatty acids in the rumen. Livest. Prod. Sci. 39:61-69.

Erfle, J. D., F. D. Sauer and S. Mahadevan. 1976. Effect of ammonia concentration on activity of enzymes of ammonia assimilation and on synthesis of amino acids by mixed rumen bacteria in continuous culture. J. Dairy Sci. 60:1064-1072.

Etman, K. E. I., I. M. Soliman, I. A. S. Abou-Selim and A. A. Soliman. 1993. Cassava (Manihot esculenta, crantz.) in rations of buffaloes: E. Effect of partial replacement of yellow corn by cassava pellets in rations of growing buffaloes calves. In: Prospects of buffaloes production in the Mediterranean and the middle east (Ed. M. Shafie, A. H. Barkawi, S. A. Ibrahim and R. R. Sadek). Cairo, Egypt. Pudoc Scientific Publishers, Wageningen. pp. 302-304.

Galyean, M. 1989. Laboratory procedure in animal nutrition research. Department of Animal and Life Science. New Mexico State University, USA. p. 193.

Granum, G., M. Wanapat, P. Pakdee, C. Wachirapakorn and W. Toburan. 2007. A comparative study on the effect of cassava hay supplementation in swamp buffaloes (Bubalus bubalis) and cattle (Bos indicus). Asian-Aust. J. Anim. Sci. 20:13891396.

Firkins, J. L. 1996. Maximizing microbial protein synthesis in the rumen. J. Nutr. 126:1347S-1354S.

Firkins, J. L., A. N. Hristov, M. B. Hall, G. A. Varga and N. R. StPierre. 2006. Integration of ruminal metabolism in dairy cattle. J. Dairy Sci. 89:E31-E51.

Foiklang, S. and M. Wanapat, 2010. Effect of carbohydrate sources and hi-pro feed on rumen fermentation and nutrient digestibility in beef cattle. Proceeding of the $11^{\text {st }}$ Animal Science Agriculture Seminar, Department of Animal Science, Khon Kaen University.

Hungate, R. E. 1966. The rumen and its microbes. Academic Press. New York and London. p. 533.

Hungate, R. E. 1969. A roll tube method for cultivation of strict anaerobes. In: Methods in Microbiology, edited by Norris (Ed. J. R. Norris and D. W. Ribbons), New York. Academic. p. 313117.

Keady, T. W. J. and C. S. Mayne. 2001. The effects of concentrate energy source on feed intake and rumen fermentation parameters of dairy cows offered a range of grass silage. Anim. Feed Sci. Technol. 90:117-129.

Khampa, S., M. Wanapat, C. Wachirapakorn, N. Nontaso and M. 
Wattiaux. 2006. Effects of urea level and sodium DL-malate in concentrate containing high cassava chip on ruminal fermentation efficiency, microbial protein synthesis in lactating dairy cows raised under tropical condition. Asian-Aust. J. Anim. Sci. 19:837-841.

Khan, M. A., H. J. Lee, W. S. Lee, H. S. Kim, S. B. Kim, S. B. Park, K. S. Baek, J. K. Ha and Y. J. Choi. 2008. Starch source evaluation in calf starter: II. Ruminal parameters, rumen development, nutrient digestibilities, and nitrogen utilization in Holstein calves. J. Dairy Sci. 91:1140-1149.

Lesmeister, K. E. and A. J. Heinrichs. 2004. Effects of corn processing on growth characteristics, rumen development and rumen parameters in neonatal dairy calves. J. Dairy Sci. 87:3439-3450.

Margarida, M., B. Chhorn, L. Phillip and H. Klesius. 2002. Effect of soybean meal replacement by cottonseed meal and iron supplementation on growth, immune response and resistance of Channel Catfish (Ictalurus puctatus) to Edwardsiella ictaluri challenge. Aquaculture 207:263-279.

Owen, F. G., D. W. Kellogg and W. T. Howard. 1967. Effect of molasses in normal- and high-grain rations on utilization of nutrients for lactation. J. Dairy Sci. 50:1120-1125.

Promkot, C. and M. Wanapat. 2005. Effect of level of crude protein and use of cottonseed meal in diets containing cassava chips and rice straw for lactating dairy cows. Asian-Aust. J. Anim. Sci. 18:502-511.

Promkot, C., M. Wanapat, C. Wachirapakorn and C. Navanukraw. 2007. Influence of sulfur on fresh cassava foliage and cassava hay incubated in rumen fluid of beef cattle. Asian-Aust. J. Anim. Sci. 20:1424-1432.

Richardson, J. M., R. G. Wilkinson and L. A. Sinclair. 2003. Synchrony of nutrient supply to the rumen and dietary energy source and their effects on the growth and metabolism of lambs. J. Anim. Sci. 81:1332-1347.

Rusche, W. C., R. C. Cochran, L. R. Corah, J. S. Stevenson, D. L. Harmon, R. T. Jr. Brandt. and J. E. Minton. 1993. Influence of source and amount of dietary protein on performance, blood metabolites, and reproductive function of primiparous beef cows. J. Anim. Sci. 71:557-563.

Russell, J. B. and J. L. Rychlik. 2001. Factors that alter rumen microbial ecology. Science 292:1119-1122.

Samuel, M., S. Sagathewan, J. Thomas and G. Mathen. 1997. An HPLC method for estimation of volatile fatty acids of ruminal fluid. Indian J. Anim. Sci. 67:805-807.

SAS. User's Guide: Statistic, Version 5. Edition. 1996. SAS. Inst Cary, NC., USA.

Sarwar, M., J. L. Firkins and M. Eastridge. 1991. Effect of replacing neutral detergent fiber of forage with soyhulls and corn gluten feed for dairy heifers. J. Dairy Sci. 74:1006-1017.

Singh, M., K. Sharma, N. Dutta, P. Singh, A. K. Verma and U. R. Mehra. 2007. Estimation of rumen microbial protein supply using urinary purine derivatives excretion in crossbred calves fed at different levels of feed intake. Asian-Aust. J. Anim. Sci. 20:1567-1574.

Sommart, K., D. S. Parker, P. Rowlinson and M. Wanapat. 2000. Fermentation characteristics and microbial protein synthesis in an in vitro system using cassava, rice straw and dried ruzi grass as substrates. Asian-Aust. J. Anim. Sci. 13:1084-1093.

Sommart, K., M. Wanapat, P. Rowlinson and D. S. Parker. 1997.
The effects of nonstructural carbohydrate and dietary protein on feed intake, ruminal fermentation and cow performance. In: Proceedings of the British Society of Animal Science, March 1997. British Society of Animal, Scarborough, England, UK. p. 97.

Stern, M. D. and W. H. Hoover. 1979. Methods for determining and factors affecting rumen microbial protein synthesis: a review. J. Anim. Sci. 49:1590-1603.

Swartz, L. A., A. J. Heinrichs, G. A. Varga and L. D. Muller. 1991. Effects of varying dietary undegradable protein on dry matter intake, growth, and carcass composition of Holstein calves. J. Dairy Sci. 74:3884-3890.

Tajima, M., R. I. Aminov, T. Nagamine, H. Matsui, M. Nakamura and Y. Benno. 2001. Diet-dependent shifts in the bacterial population of the rumen revealed with real-Time PCR. Appl. Environ. Microbiol. 67:2766-2774.

Titi, H. H. 2003. Replacing soybean meal with sunflower meal with or without fibrolytic enzymes in fattening diets of goat kids. Small Rumin. Res. 48:45-50.

Van Soest, P. J., J. B. Robertson and B. A. Lewis. 1991. Methods of dietary fiber, neutral detergent fiber and non-starch carbohydrates in relation to animal nutrition. J. Dairy Sci. 74:3583-3597.

Wanapat, M. 2003. Manipulation of cassava cultivation and utilization to improve protein to energy biomass for livestock feeding in the tropics. Asian-Aust. J. Anim. Sci. 16:463-472.

Wanapat, M. and S. Khampa. 2007. Effect of levels of supplementation of concentrate containing high levels of cassava chip on rumen ecology, microbial $\mathrm{N}$ supply and digestibility of nutrients in beef cattle. Asian-Aust. J. Anim. Sci. 20:75-81.

Wanapat, M. and R. Pilajan. 2009. Effect of hi-pro feed and carbohydrate sources on rumen fermentation and milk production in dairy milking cows. Proceeding of the $10^{\text {th }}$ Animal Science Agriculture Seminar, Department of Animal Science, Khon Kaen University.

Wanapat, M., R. Pilajun and P. Kongmun. 2009a. Ruminal ecology of swamp buffalo as influenced by dietary sources. Anim. Feed Sci. Technol. 151:205-214.

Wanapat, M., R. Pilajun and P. Rowlinson. 2012. Effect of carbohydrate source and cottonseed meal level in the concentrate: IV. Feed intake, rumen fermentation and milk production in milking cows. Trop. Anim. Health Prod. 45:447453.

Wanapat, M., S. Polyorach, K. Boonnop, C. Mapato and A. Cherdthong. 2009b. Effects of treating rice straw with urea or urea and calcium hydroxide upon intake, digestibility, rumen fermentation and milk yield of dairy cows. Livest. Sci. 125:238-243

Wang, Y. H., M. Xua, F. N. Wang, Z. P. Yu, J. H. Yao, L. S. Zan and F. X. Yang. 2009. Effect of dietary starch on rumen and small intestine morphology and digesta $\mathrm{pH}$ in goats. Livest. Sci. 122:48-52

Wora-Anu, S., M. Wanapat, C. Wachirapakorn and N. Nontaso. 2007. Effect of roughage sources on cellulolytic bacteria and rumen ecology of beef cattle. Asian-Aust. J. Anim. Sci. 20:1705-1712. 